\title{
Fen Bilgisi Öğretmen Adaylarının Çevre Eğitimi Öz-yeterlik Algılarının Farklı Değişkenler Açısından İncelenmesi ${ }^{a}$
}

\author{
Çiğdem Çıngıl Barışb,c
}

\section{Özet}

$\mathrm{Bu}$ araştırmanın amacl, fen bilgisi öğretmen adaylarının çevre eğitimi konusundaki öz-yeterlik algılarının farklı değişkenler açısından incelenmesidir. Araştırmanın örneklemini, 225 fen bilgisi öğretmen adayı oluşturmaktadır. Verilerin toplanmasında, Özdemir, Aydın ve Akar-Vural (2009) tarafından geliştirilen "Çevre Eğitimine Yönelik Öz-yeterlik Alg1 Ölçeği" kullanılmıştır. Verilerin analizinde SPSS 21.0 kullanılmıştır. Araştırmanın sonucuna göre; fen bilgisi öğretmen adaylarının çevre eğitimine yönelik öz-yeterlik algılarının orta seviyede olduğu; “Öğretici Yetkinlik Algısı" alt boyutu dışında cinsiyete göre anlamlı bir farklılığın olmadığı, sınıf seviyesine göre ise tüm alt boyutlarda anlamlı farklılıkların olduğu belirlenmiştir. Ayrıca, çevre eğitimi dersi alan fen bilgisi öğretmen adaylarının algılarını, dersi almayanlara göre yüksek olduğu görülmektedir.
Anahtar Kelimeler

Çevre Eğitimi

Öz-Yeterlik Algısı

Fen Bilgisi Öğretmen Adayları

Çevre Eğitimi Öz-yeterlik Algısı

Makale Hakkında

Geliş Tarihi: 03.01.2020

Kabul Tarihi: 25.12.2020

Doi: 10.18026/cbayarsos.670078

\section{Investigation of Pre-service Science Teachers Self-efficacy Perceptions toward Environmental Education in Terms of Different Variables}

\begin{abstract}
The aim of this research is to examine the self-efficacy perceptions of preservice science teachers on environmental education in terms of different variables. The sample of the study consists of 225 pre-service science teachers. As a data collection tool, "The Scale of Self-efficacy Perception toward Environmental Education" developed by Özdemir, Aydın and Akar-Vural (2009) was used. SPSS 21.0 was used for data analysis. According to the results of the research; it was determined that pre-service science teachers' perception of environmental education self-efficacy was moderate level and that the perception levels did not show a significant difference according to the genders except "Instructive Competence Perception" subdimension, and there were significant differences in all subdimensions by class levels. In addition, it is seen that the perceptions of the pre-service science teachers who take environmental education courses are higher than those who do not take.
\end{abstract}

Keywords

Environmental Education

Self-efficacy Perception

Pre-service Science Teachers

Self-efficacy Perception toward

Environmental Education

About Article

Received: 03.01.2020

Accepted: 25.12 .2020

Doi: $10.18026 /$ cbayarsos.670078

\footnotetext{
a Bu araştırma 12-15 Eylül 2017 tarihlerinde düzenlenen XIII. Uluslararası Katılımlı Ekoloji ve Çevre Kongresi'nde sözlü bildiri olarak sunulmuştur. b E-mail: ccingil@istanbul.edu.tr

c Dr. Öğretim Üyesi, “İstanbul Üniversitesi-Cerrahpaşa”, HAYEF, Matematik ve Fen Bilimleri Eğitimi Bölümü, Fen Bilgisi Eğitimi Anabilim Dalı, ORCID No: 0000-0003-0698-5157
} 


\section{Giriş}

Sosyal Öğrenme Kuramı́nın öncü ismi olan Albert Bandura tarafından tanımlanan öz-yeterlik kavramı, bir işin başarılmasında bireyin kendisine olan inancını kapsamaktadır. Öz-yeterlik, insanların belirli bir düzeyde gerçekleştirmeleri gereken faaliyetleri yönetme kapasitelerine ve bu faaliyetleri başarıyla yürütme yeteneklerine ilişkin yargıları olarak tanımlanmaktadır (Bandura, 1986). Öz-yeterlik inancı, bir kişinin bir işi başlatması ve bu işi başarı ile tamamlaması yeteneğini etkileyen en önemli faktörlerden biridir. Ayrıca, kişinin nasıl hissedebildiğini, düşünebildiğini, kendini nasıl motive edip nasıl davranışlar sergileyebildiğini belirleyen önemli bir kriterdir (Bandura, 1994).

Öz-yeterlik üzerine yapılan araştırmalarda, iki unsur üzerine yoğunlaşıldığı görülmektedir. $\mathrm{Bu}$ unsurlar öğretmen ve öğretmen adaylarıdır. Öğretmenlerin yeterli alan bilgisi ile öğretim yöntem ve tekniklerini uygulama bilgi ve becerisine sahip olmalarının yanı sıra; bu bilgi ve becerileri uygulamaya geçirebilme yönünde inanç sahibi olmaları mesleklerini etkin bir biçimde icra etmelerinde oldukça önemlidir (Kahyaoğlu, 2011). Öğretmenlerin sahip oldukları öz-yeterlik seviyesi yararlı bir okul ortamının inşa edilmesinde önemli bir etmendir (Bıkmaz, 2004). Öğretmenlerin özellikle öğretmenlik öz-yeterlik algılarının, öğrencilerinin öğrenmesi ile yakından ilişkili olduğu tespit edilmiştir (Armor ve diğ., 1976). Öz-yeterliği yüksek olan bir öğretmen, sınıf ortamında istekli bir biçimde zamanı daha iyi kullanarak daha uzun süreler boyunca çalışabilmektedir (Gibson ve Dembo, 1984). Öğretmenlerin öz-yeterlik algısı ile öğretme becerileri arasındaki ilişkinin incelendiği araştırmaların sonucuna göre, öğrencilerin öz-yeterliği yüksek olan öğretmenlerinin öğretme becerilerini yüksek olarak algıladıkları ve onlara daha fazla sayg1 duydukları görülmüştür (Gorski, Davis ve Reiter, 2012; Miller, Ramirez ve Murdock, 2017). Öz-yeterliliği yüksek olan öğretmenlerin öğrencilerinin de akademik başarılarının yükseldiği, sınıf ortamında daha fazla etkinlik planlanıldığı ve etkileşimin fazlalaştığı kaliteli bir sınıf ortamının yaratıldığ görülmektedir. Bu şekilde, öğrencinin gelişimi ile birlikte öğretmenin öz-yeterliği artmaya devam etmekte ve mesleğine kendini daha fazla adamaktadır (Schunk, 2014).

Çevre sorunlarının etkilerinin giderek daha fazla hissedilmesi sonucunda, alınması gerekli önlemler düşünüldüğünde çevre ile eğitim kavramlarının bir araya getirilerek verilmesinin gerekliliği ortaya çıkmaktadır. İnsanlar varoldukları andan itibaren çevre ile etkileşim içinde yaşamış, temel ihtiyaçlarını çevreden karşılamış ancak bunun yanı sıra çevreye çeşitli zararlar da vermiştir. Giderek artan çevre sorunlarının, sadece yasalarla önüne geçilemez bir duruma gelmesi nedeni ile, çevre sorunlarının çözümü olarak çevre bilinci yüksek bireylerin yetiştirilmesi hedeflenmelidir. Bu durum ise, eğitim ortamlarında etkili bir biçimde çevre eğitimi dersinin verilmesi ile mümkün olmaktadır. Çevre eğitimi, insanların çevreleri ile uyumlu ve bilinçli bir biçimde yaşamlarını sürdürmelerini ve bu doğrultuda çevreye karşı duyarlı ve farkındalık kazanmış bireyler olarak yetiştirilmelerini hedefleyen ve bu şekilde işlenen bir eğitim-öğretim sürecidir. Bu gibi sebeplerle, çevre eğitiminin verilmesi ile birlikte, bireylerin yaşamlarında olumlu yönde tutum ve davranışlar geliştirilmesi hedeflenmektedir (Özdemir, 2007). Çevre eğitiminin esas amacı; bireylerin çevreye yönelik sorumlu davranışları sergileyebilmelerine imkan tanıyan ve heveslendiren bilgiler, yetenekler ve değer yargılarına sahip olarak kuşatılmış yurttaşlar olarak yetişebilmelerinin sağlanmasıdır (Doğan, 1997). Böylelikle çevre eğitimi sayesinde doğal kaynakların makul şekilde kullanımının sağlanması, çevre kirlenmesinin engellenmesi, çevrenin kendini yenileyebilme kabiliyetinin muhafaza edilmesi, bireylere çevre bilinci ile birlikte pozitif tutum ve davranışların kazandırılması 
hedeflenmektedir (ÇEDGM, 2004). Çevre eğitiminin sonucunda, ihtiyacından fazlasını tüketmeyen, sonraki nesillere karşı sorumlu olduğunun farkına varan, çevre problemleri hususunda bilinçli ve hassas bir insan şekli yetiştirilmesi amaçlanmaktadır (Kurgun, Aydın ve Tarkay, 2003).

Çevre eğitimini uygulamalarında en önemli etmenlerin başında öğretmenlerin öz-yeterlikleri gelmektedir (Moseley, Huss ve Utley, 2010). Bir öğretmenin çevre eğitimini etkili bir biçimde uygulayabileceğine dair kendine olan inancı çevre eğitimi öz-yeterliği olarak ifade edilebilir (Moseley, Reinke ve Bookout, 2002). Çevre eğitimi öz-yeterlik inançları ile öğretmenlerin kişisel ve mesleki deneyimleri (Trauth-Nare, 2015), öğrencilerin performansları ile öğretmenlerin öğretme hususundaki öz-yeterlikleri yakın bir ilişki halindedir (Leithwood ve Jantzi, 2008). Bu sebeple, öğretmenlerin çevre eğitimini etkili bir biçimde uygulayabilmeleri için ilk olarak kendilerinin yeterli çevre eğitimi almış olması, çevre ile ilgili olumlu tutum ve davranışlar geliştirmiş olması ve çevre eğitimi öz-yeterlik inançlarının yüksek olması gerekmektedir. Etkili bir çevre eğitimi uygulaması için, öğretmenlerin daha birer öğretmen adayı iken edindikleri diğer bilgi ve becerilerin yanı sıra, etkin bir çevre eğitimi dersi almış olmaları, çevre etkinliklerine katılmaları ve bu yönde olumlu tutumlar geliştirmiş olmaları gerekmektedir (Plevyak vd., 2001).

$\mathrm{Bu}$ bağlamda yapılan bu araştırmada, fen bilgisi öğretmen adaylarının çevre öz-yeterlik algılarının seviyelerinin tespit edilmesi ve çeşitli değişkenler açısından incelenmesi amacı ile aşağıdaki alt problemlerin cevapları aranmıştır:

1. Fen bilgisi öğretmen adaylarının çevre eğitimi öz-yeterlik algıları hangi düzeydedir?

2. Fen bilgisi öğretmen adaylarının çevre eğitimi öz-yeterlik algıları cinsiyete göre anlamlı farklılık göstermekte midir?

3. Fen bilgisi öğretmen adaylarının çevre eğitimi öz-yeterlik algıları sınıf seviyesine göre anlamlı farklılık göstermekte midir?

4. Fen bilgisi öğretmen adaylarının çevre eğitimi öz-yeterlik algıları en uzun süre yaşadıkları coğrafi bölgeye göre anlamlı farklılık göstermekte midir?

5. Fen bilgisi öğretmen adaylarının çevre eğitimi öz-yeterlik algıları çocukluğun geçirildiği yerleşim yerine göre anlamlı farklılık göstermekte midir?

6. Fen bilgisi öğretmen adaylarının çevre eğitimi öz-yeterlik algıları çevre eğitimi dersi alıp almamalarına göre anlamlı farklılık göstermekte midir?

\section{Yöntem}

\section{Araştırma Modeli}

$\mathrm{Bu}$ araştırma, fen bilgisi öğretmen adaylarının çevre eğitimi öz-yeterlik algılarının belirlenmesine yönelik ilişkisel tarama modelindedir. Tarama modelleri şimdi veya eskiden var olan bir vaziyeti var olduğu biçimi ile betimlemek amacı ile düzenlenen araştırmalar için uygun bir modeldir. Bu araştırmada kullanılan ilişkisel tarama modelinde, belirli hedeflere erişmek için spesifik vakalar arasında var olan bağlantıyı açıklamaya ve iki ya da daha fazla parametrenin arasında yer alan beraber değişimlerinin varlığı ve/veya mertebesi tespit edilmeye çalışılmıştır (Karasar, 2008). 


\section{Evren ve Örneklem}

Araştırmanın örneklemini, İstanbul'da devlete ait bir üniversitenin Eğitim Fakültesinde Matematik ve Fen Bilimleri Eğitimi Bölümü, Fen Bilgisi Eğitimi Anabilim Dalı'nda öğrenim görmekte olan 225 öğretmen adayı oluşturmaktadır. Katılımcıların 49'u (\%21.8) birinci sınıf, 62'si (\%27.6) ikinci sınıf, 57' si (\%25.3) üçüncü sınıf, 57'si (\%25.3) dördüncü sınıf; aynı zamanda 193 'ü (\%85.8) kadın, 32'si (\%15.8) erkek'tir.

\section{Veri Toplama Araçları}

$\mathrm{Bu}$ araştırmada veri toplama aracı olarak, "Kişisel Bilgi Formu" ve Özdemir, Aydın, AkarVural (2009) tarafından geliştirilen "Çevre Eğitimi Öz-yeterlik Alg1 Ölçeği"nden yararlanılmıştır. "Kişisel Bilgi Formu", öğretmen adaylarına ilişkin demografik bilgilerden oluşmaktadır. Özdemir, Aydın, Akar-Vural (2009)’ın geliştirdikleri “Çevre Eğitimi Öz-yeterlik Alg1 Ölçeği" ise, toplamda 15 madde ve 4 alt boyutu olan 5'li Likert şeklinde bir ölçektir. Bu alt boyutların isimleri ile maddelerinin numaraları şu şekildedir; Akademik Yetkinlik Algısı (1., 3., 4., 5., 7. ve 10. maddeler), Sorumluluk Algısı (8., 13. ve 14. maddeler), Öğretici Yetkinlik Alg1sı (2., 11. ve 15. maddeler), Yönlendirebilme Alg1sı (6., 9. ve 12. maddeler). Ölçekten elde edilebilecek puanlara göre, en fazla alınabilecek puan 75 iken, alınabilecek en düşük puanın ise 15 olduğu görülmektedir. Alınan puanın yüksekliği öz-yeterlik inançlarının yüksekliğini, alınan düşük puanlar ise öz-yeterlik inançlarının düşüklüğünü göstermektedir. Ölçeğe ait alt boyutların Cronbach Alpha güvenirlik değerleri sırası ile 0.79, 0.86, 0.74, ve 0.68 olarak tespit edilirken, ölçeğin totali için bu değer 0.76 olarak hesaplanmıştır.

\section{Verilerin Toplanması ve Analizi}

Veri toplama araçları öğretmen adaylarına araştırmacı tarafından uygulanmıştır. Verilerin girişleri sırasında eksik doldurulan kağıtlar elenmiş ve girişleri yapılmıştır. Verilerin analizinde SPSS 21.0 programından yararlanılmıştır. Analizlerin yapılmasından önce verilerin normallikleri Kolmogorov-Smirnov normalite testlerine göre incelenmiştir. Değişkenlerin normal dağılım gösterdiği belirlendiğinden parametrik testlere göre analizler yapılmıştır. Ölçekten elde edilen ortalama puanların demografik değişkenlere göre incelenmesi İlişkisiz Grup t-testi ile Tek Yönlü Varyans Analizi (ANOVA) uygulanarak yapılmıştır.

\section{Bulgular}

Bu bölümde, fen bilgisi öğretmen adaylarının çevre eğitimi öz-yeterlik algılarının düzeyleri ile cinsiyet, öğrenim görülen sınıf seviyesi, en uzun süre yaşanılan coğrafi bölge, çocukluğun geçirildiği yerleşim yeri ve çevre eğitimi dersi alıp almama durumu arasındaki ilişkilere ait bulgular ve analizler yer almaktadır.

Araştırma problemlerinin sırasına göre, “Fen Bilgisi Öğretmen Adaylarının Çevre Eğitimi Özyeterlik Algı düzeyleri hangi düzeydedir?" şeklindeki ilk alt probleme yanıt bulmak üzere ÇÖAÖ'den ve her bir boyut için ortalama puanlar hesaplanmış ve bulgular Tablo 1'de sunulmuştur. 
Tablo 1. Fen Bilgisi Öğretmen Adaylarının ÇÖAÖ Ortalama Puanları

\begin{tabular}{lccc}
\hline Ölçek Boyutları & $\mathbf{X}$ & SS & Düzey \\
\hline Akademik Yetkinlik Algısı & 3.210 & .56 & Orta \\
Sorumluluk Algisı & 3.084 & .88 & Orta \\
Öğretici Yetkinlik AlgıSı & 3.877 & .63 & Yüksek \\
Yönlendirebilme Algisı & 2.579 & .73 & Düşük \\
ÇÖAÖ Toplam & 3.192 & .41 & Orta \\
\hline
\end{tabular}

ÇÖAÖ'den alınabilecek puan aralığı 15 ile 75 arasındadır. Öğretmen adaylarının aldıkları puanlara göre alg1 seviyelerini tespit etmek için, ölçeğin aralıklarının genişliği, "dizi genişliği/yapılacak grup sayısı" (4/5=0.80) formülünden yararlanılarak hesaplanmıştır (Tekin, 1993). Ölçeğin aritmetik ortalama aralıkları; 1.00-1.79 'Çok düşük', 1.80-2.59 ‘Düşük', 2.60-3.39 'Orta', 3.40-4.19 'Yüksek', 4.20-5.00 'Çok yüksek' olarak belirlenmiştir. Bu sonuca göre, "Öğretici Yetkinlik Alg1sı" boyutu için yüksek, "Akademik Yetkinlik Alg1sı" ve "Sorumluluk Algısı" boyutları için orta, "Yönlendirebilme Alg1sı" boyutu için düşük olmakla birlikte, ölçeğin tümü için fen bilgisi öğretmen adaylarının çevre eğitimi öz-yeterlik algılarının "orta" seviyede olduğu bulunmuştur.

“Fen bilgisi öğretmen adaylarının çevre eğitimi öz-yeterlik algıları cinsiyete göre anlamlı farklılık göstermekte midir?" şeklindeki alt probleme cevap bulmak amacı ile ilişkisiz grup ttesti uygulanmış ve bulguları Tablo 2' de sunulmuştur.

Tablo 2. Fen Bilgisi Öğretmen Adaylarının ÇÖAÖ ve Alt Boyutları için “Cinsiyet” Değişkenine Göre İlişkisiz Grup t-testi Sonuçları

\begin{tabular}{|c|c|c|c|c|c|c|c|c|}
\hline Ölçek Boyutları & Cinsiyet & $\mathbf{N}$ & $\bar{X}$ & SS & $\mathrm{SH}_{x}$ & $t$ & Sd & $\bar{p}$ \\
\hline \multirow{2}{*}{$\begin{array}{c}\text { Akademik } \\
\text { Yetkinlik Algisı }\end{array}$} & Kadın & 193 & 19.295 & 3.106 & 0.223 & 0.361 & 223 & 0.718 \\
\hline & Erkek & 32 & 19.062 & 4.731 & 0.836 & & & \\
\hline \multirow{2}{*}{$\begin{array}{c}\text { Sorumluluk } \\
\text { Algisı }\end{array}$} & Kadın & 193 & 9.326 & 2.667 & 0.192 & 1.016 & 223 & 0.311 \\
\hline & Erkek & 32 & 8.812 & 2.545 & 0.450 & & & \\
\hline \multirow{2}{*}{$\begin{array}{c}\text { Öğretici } \\
\text { Yetkinlik Alg1sı }\end{array}$} & Kadın & 193 & 11.808 & 1.782 & 0.128 & 3.490 & 223 & 0.001 \\
\hline & Erkek & 32 & 10.562 & 2.341 & 0.413 & & & \\
\hline \multirow{2}{*}{$\begin{array}{c}\text { Yönlendirebilme } \\
\text { Algisı }\end{array}$} & Kadın & 193 & 7.673 & 2.184 & 0.157 & -1.074 & 223 & 0.284 \\
\hline & Erkek & 32 & 8.125 & 2.310 & 0.408 & & & \\
\hline \multirow[t]{2}{*}{ ÇÖAÖ Toplam } & Kadın & 193 & 48.103 & 5.777 & 0.416 & 1.284 & 223 & 0.200 \\
\hline & Erkek & 32 & 46.562 & 8.813 & 1.558 & & & \\
\hline
\end{tabular}

Tablo 2'de görüldüğü gibi, ilişkisiz grup t-testi sonucunda, "Akademik Yetkinlik Algısı", "Sorumluluk Algısı" ile "Yönlendirebilme Algısı" boyutları ile ölçek toplam ortalama puanları arasında anlamlı fark bulunmazken ( $\mathrm{p}>0.05)$, “Öğretici Yetkinlik Algısı" boyutu için kadınların lehine anlamlı yönde farklılık bulunmuştur $(\mathrm{p}<0.05)$. 
Araştırmada; "Fen bilgisi öğretmen adaylarının çevre eğitimi öz-yeterlik algıları sınıf seviyesine göre anlamlı farklılık göstermekte midir?" şeklindeki alt probleme cevap bulmak üzere, ANOVA yapılmış ve sonuçlar Tablo 3'te sunulmuştur.

Tablo 3. Fen Bilgisi Öğretmen Adaylarının ÇÖAÖ ve Alt Boyutları için "Sınıf" Değişkenine Göre ANOVA Sonuçları

\begin{tabular}{|c|c|c|c|c|c|c|c|c|c|c|}
\hline Ölçek Boyutları & Sinif & $\mathbf{N}$ & $x$ & SS & Var.K. & K.T. & SD & K.O & $\mathbf{F}$ & p \\
\hline \multirow{5}{*}{$\begin{array}{c}\text { Akademik } \\
\text { Yetkinlik Algisı }\end{array}$} & 1. & 49 & 19.326 & 3.54958 & G. Arası & 71.007 & 3 & 23.669 & 2.112 & 0.100 \\
\hline & 2. & 62 & 18.661 & 2.79310 & G. İçi & 2476.522 & 221 & 11.206 & & \\
\hline & 3. & 57 & 18.982 & 3.74877 & Toplam & 2547.529 & 224 & & & \\
\hline & 4. & 57 & 20.140 & 3.29739 & & & & & & \\
\hline & Toplam & 225 & 19.262 & 3.37237 & & & & & & \\
\hline \multirow{5}{*}{$\begin{array}{l}\text { Sorumluluk } \\
\text { Algisı }\end{array}$} & 1. & 49 & 10.204 & 2.52471 & G. Aras1 & 152.162 & 3 & 50,721 & 7.881 & 0.000 \\
\hline & 2. & 62 & 8.645 & 2.65563 & G. İçi & 1422.398 & 221 & 6.436 & & \\
\hline & 3. & 57 & 8.315 & 2.65355 & Toplam & 1574.560 & 224 & & & \\
\hline & 4. & 57 & 10.035 & 2.28321 & & & & & & \\
\hline & Toplam & 225 & 9.253 & 2.65128 & & & & & & \\
\hline \multirow{5}{*}{$\begin{array}{c}\text { Öğretici } \\
\text { Yetkinlik Algısı }\end{array}$} & 1. & 49 & 11.326 & 2.41857 & G. Arasi & 27.022 & 3 & 9.007 & 2.503 & 0.060 \\
\hline & 2. & 62 & 11.274 & 2.04193 & G. İçi & 795.360 & 221 & 3.599 & & \\
\hline & 3. & 57 & 12.105 & 1.60005 & Toplam & 822.382 & 224 & & & \\
\hline & 4. & 57 & 11.807 & 1.44468 & & & & & & \\
\hline & Toplam & 225 & 11.631 & 1.91608 & & & & & & \\
\hline \multirow{5}{*}{$\begin{array}{l}\text { Yönlendirebilme } \\
\text { Algısı }\end{array}$} & 1. & 49 & 7.816 & 2.22367 & G. Arasi & 3.370 & 3 & 1.123 & 0.229 & 0.876 \\
\hline & 2. & 62 & 7.677 & 2.18620 & G. İçi & 1084.158 & 221 & 4.906 & & \\
\hline & 3. & 57 & 7.578 & 2.17081 & Toplam & 1087.529 & 224 & & & \\
\hline & 4. & 57 & 7.894 & 2.28101 & & & & & & \\
\hline & Toplam & 225 & 7.737 & 2.20342 & & & & & & \\
\hline \multirow{5}{*}{ ÇÖAÖ Toplam } & 1. & 49 & 48.673 & 7.90672 & G. Aras 1 & 467.226 & 3 & 155.742 & 4.091 & 0.007 \\
\hline & 2. & 62 & 46.258 & 5.28200 & G. İçi & 8413.769 & 221 & 38.071 & & \\
\hline & 3. & 57 & 46.982 & 6.08127 & Toplam & 8880.996 & 224 & & & \\
\hline & 4. & 57 & 49.877 & 5.41186 & & & & & & \\
\hline & Toplam & 225 & 47.884 & 6.29661 & & & & & & \\
\hline
\end{tabular}

Tablo 3'te görüldüğü üzere, ölçeğin tümü için $\left[\mathrm{F}_{(4-220)}=4.091, \mathrm{p}<.05\right]$ ve "Sorumluluk Algisi" $\left[\mathrm{F}_{(4-220)}=7.881, \mathrm{p}<.00\right]$ boyutu aritmetik ortalamaları arasında anlamlı farka rastlanmıştır. ANOVA sonrası uygulanan post-hoc analiz tekniklerinden Tukey HSD seçilmiş ve bu testin sonucuna göre, öğretmen adaylarının ÇÖAÖ puanları incelendiğinde 1. ve 4. sınıf öğretmen adaylarının "Sorumluluk Algısı" boyutu puanlarının 2. ve 3. sınıf öğretmen adaylarının puanlarından anlamlı düzeyde yüksek olduğu bulunmuştur. Ayrıca, 4. sınıf öğretmen adaylarının ÇÖAÖ'den aldıkları toplam puanların 2. sınıf öğretmen adaylarının puanlarından anlamlı düzeyde yüksek olduğu tespit edilmiştir.

Araştırmada; “Fen bilgisi öğretmen adaylarının çevre eğitimi öz-yeterlik algıları en uzun süre yaşadıkları coğrafi bölgeye göre anlamlı farklılık göstermekte midir?” şeklindeki alt probleme yanıt bulmak üzere ANOVA yapılmış ve sonuçları Tablo 4'te sunulmuştur. 
Tablo 4. Fen Bilgisi Öğretmen Adaylarının ÇÖAÖ ve Alt Boyutları için “En uzun süre yaşanılan coğrafi bölge" Değişkenine Göre ANOVA Sonuçları

\begin{tabular}{|c|c|c|c|c|c|c|c|c|c|c|}
\hline Ölçek Boyutları & Sinif & $\mathbf{N}$ & $X$ & SS & Var.K. & K.T. & SD & K.O & $\mathbf{F}$ & $\mathrm{p}$ \\
\hline \multirow{8}{*}{$\begin{array}{c}\text { Akademik } \\
\text { Yetkinlik Alg1sı }\end{array}$} & İç Anadolu & 2 & 25.000 & 0.000 & G. Aras1 & 147.559 & 6 & 24.593 & \multirow{8}{*}{2.234} & \multirow{8}{*}{0.041} \\
\hline & $\begin{array}{l}\text { Doğu } \\
\text { Anadolu }\end{array}$ & 3 & 18.333 & 4.163 & G. İçi & 2399.970 & 218 & 11.009 & & \\
\hline & $\begin{array}{l}\text { Güneydoğu } \\
\text { Anadolu }\end{array}$ & 3 & 20.333 & 3.214 & Toplam & 2547.529 & 224 & & & \\
\hline & Karadeniz & 12 & 16.833 & 2.823 & & & & & & \\
\hline & Akdeniz & 11 & 19.454 & 3.777 & & & & & & \\
\hline & Ege & 10 & 19.900 & 3.212 & & & & & & \\
\hline & Marmara & 184 & 19.309 & 3.323 & & & & & & \\
\hline & Toplam & 225 & 19.262 & 3.372 & & & & & & \\
\hline \multirow{8}{*}{ Sorumluluk Alg1sı } & İç Anadolu & 2 & 13.000 & 0.000 & G. Arasi & 58.572 & 6 & 9.762 & \multirow{8}{*}{1.404} & \multirow{8}{*}{0.214} \\
\hline & $\begin{array}{l}\text { Doğu } \\
\text { Anadolu }\end{array}$ & 3 & 10.000 & 4.358 & G. İçi & 1515.988 & 218 & 6.954 & & \\
\hline & $\begin{array}{l}\text { Güneydoğu } \\
\text { Anadolu }\end{array}$ & 3 & 9.666 & 1.154 & Toplam & 1574.560 & 224 & & & \\
\hline & Karadeniz & 12 & 7.916 & 2.937 & & & & & & \\
\hline & Akdeniz & 11 & 8.545 & 2.464 & & & & & & \\
\hline & Ege & 10 & 9.100 & 2.024 & & & & & & \\
\hline & Marmara & 184 & 9.331 & 2.647 & & & & & & \\
\hline & Toplam & 225 & 9.253 & 2.651 & & & & & & \\
\hline \multirow{8}{*}{$\begin{array}{c}\text { Öğretici Yetkinlik } \\
\text { Algısı }\end{array}$} & İç Anadolu & 2 & 10.0000 & 0.000 & G. Aras1 & 32.545 & 6 & 5.424 & \multirow{8}{*}{1.497} & \multirow{8}{*}{0.180} \\
\hline & $\begin{array}{l}\text { Doğu } \\
\text { Anadolu }\end{array}$ & 3 & 11.3333 & 3.055 & G. İçi & 789.837 & 218 & 3.623 & & \\
\hline & $\begin{array}{l}\text { Güneydoğu } \\
\text { Anadolu }\end{array}$ & 3 & 11.6667 & 0.577 & Toplam & 822.382 & 224 & & & \\
\hline & Karadeniz & 12 & 10.4167 & 2.151 & & & & & & \\
\hline & Akdeniz & 11 & 12.1818 & 1.401 & & & & & & \\
\hline & Ege & 10 & 11.0000 & 1.825 & & & & & & \\
\hline & Marmara & 184 & 11.7337 & 1.913 & & & & & & \\
\hline & Toplam & 225 & 11.6311 & 1.916 & & & & & & \\
\hline \multirow{8}{*}{$\begin{array}{l}\text { Yönlendirebilme } \\
\text { Alg1sı }\end{array}$} & İç Anadolu & 2 & 12.0000 & 0.000 & G. Arasi & 74.428 & 6 & 12.405 & \multirow{8}{*}{2.669} & \multirow{8}{*}{0.016} \\
\hline & $\begin{array}{l}\text { Doğu } \\
\text { Anadolu }\end{array}$ & 3 & 10.6667 & 3.214 & G. İçi & 1013.101 & 218 & 4.647 & & \\
\hline & $\begin{array}{l}\text { Güneydoğu } \\
\text { Anadolu }\end{array}$ & 3 & 7.0000 & 3.464 & Toplam & 1087.529 & 224 & & & \\
\hline & Karadeniz & 12 & 8.4167 & 1.975 & & & & & & \\
\hline & Akdeniz & 11 & 7.9091 & 2.211 & & & & & & \\
\hline & Ege & 10 & 8.0000 & 2.260 & & & & & & \\
\hline & Marmara & 184 & 7.5870 & 2.130 & & & & & & \\
\hline & Toplam & 225 & 7.7378 & 2.203 & & & & & & \\
\hline \multirow{8}{*}{ ÇÖAÖ Toplam } & İç Anadolu & 2 & 60.000 & 0.000 & G. Aras1 & 537.103 & 6 & 89.517 & \multirow{8}{*}{2.339} & \multirow{8}{*}{0.033} \\
\hline & $\begin{array}{l}\text { Doğu } \\
\text { Anadolu }\end{array}$ & 3 & 50.333 & 12.701 & G. İçi & 8343.893 & 218 & 38.275 & & \\
\hline & $\begin{array}{l}\text { Güneydoğu } \\
\text { Anadolu }\end{array}$ & 3 & 48.666 & 1.154 & Toplam & 8880.996 & 224 & & & \\
\hline & Karadeniz & 12 & 43.583 & 4.944 & & & & & & \\
\hline & Akdeniz & 11 & 48.090 & 6.171 & & & & & & \\
\hline & Ege & 10 & 48.000 & 6.960 & & & & & & \\
\hline & Marmara & 184 & 47.962 & 6.154 & & & & & & \\
\hline & Toplam & 225 & 47.884 & 6.296 & & & & & & \\
\hline
\end{tabular}

Tablo 4' te görüldügü gibi, ANOVA sonuçlarına göre gruplar arasında “Sorumluluk Algısı" ve "Öğretici Yetkinlik Algısı" boyutları için istatistiksel açıdan anlamlı bir farka rastlanmazken ( $\mathrm{p}>0.05)$, “Akademik Yetkinlik Alg1sı" $\left[\mathrm{F}_{(4-220)}=2.234, \mathrm{p}<.05\right]$ ile "Yönlendirebilme Algısı" [ $\mathrm{F}_{(4-}$ 220) $=2.669, \mathrm{p}<.05]$ boyutları ve tüm ölçekten elde edilen ortalama puanlar $\left[\mathrm{F}_{(4-220)}=2.339, \mathrm{p}<.05\right]$ için anlamlı farka rastlanmıştır $(\mathrm{p}<0.05)$. ANOVA sonrası uygulanan post-hoc analiz 
tekniklerinden Tukey HSD seçilmiş ve bu testin sonuçlarına göre, "Akademik Yetkinlik Alg1s1" ile "Yönlendirebilme Algısı" boyutları ve ölçek toplam puanına göre, en uzun süre İç Anadolu bölgesinde yaşayan öğretmen adaylarının, Karadeniz, Akdeniz, Ege ve Marmara bölgelerinde yaşayan öğretmen adaylarından anlamlı düzeyde yüksek puan aldıkları saptanmıştır $(\mathrm{p}<0.05)$.

Araştırmada; "Fen bilgisi öğretmen adaylarının çevre eğitimi öz-yeterlik algıları çocukluğun geçirildiği yerleşim yerine göre anlamlı farklılık göstermekte midir?" şeklindeki alt probleme yanıt bulmak üzere ANOVA uygulanmış ve bulgular Tablo 5'te sunulmuştur.

Tablo 5. Fen Bilgisi Öğretmen Adaylarının ÇÖAÖ ve Alt Boyutları için “Çocukluğun geçirildiği yerleşim yeri" Değişkenine Göre ANOVA Sonuçları

\begin{tabular}{|c|c|c|c|c|c|c|c|c|c|c|}
\hline Ölçek Boyutları & Sinif & $\mathbf{N}$ & $x$ & SS V & Var.K. & K.T. & & K.O & F & $\mathrm{p}$ \\
\hline \multirow{4}{*}{$\begin{array}{c}\text { Akademik Yetkinlik } \\
\text { Alg1sı }\end{array}$} & İl Merkezi & 126 & 19.230 & 3.339 & G. Arası & 72.986 & 2 & 36.493 & 3.274 & 0.040 \\
\hline & İlçe & 79 & 19.734 & 3.260 & G. İçi & 2474.543 & 222 & 11.147 & & \\
\hline & Köy & 20 & 17.600 & 3.633 & 3 Toplam & 2547.529 & 224 & & & \\
\hline & Toplam & 225 & 19.262 & 3.372 & & & & & & \\
\hline \multirow{4}{*}{ Sorumluluk Algisı } & İl Merkezi & 126 & 9.206 & 2.642 & 2 G. Aras1 & 8.580 & 2 & 4.290 & 0.608 & 0.545 \\
\hline & İlçe & 79 & 9.455 & 2.688 & G. İçi & 1565.980 & 222 & 7.054 & & \\
\hline & Köy & 20 & 8.750 & 2.613 & 3 Toplam & 1574.560 & 224 & & & \\
\hline & Toplam & 225 & 9.253 & 2.651 & & & & & & \\
\hline \multirow{4}{*}{$\begin{array}{c}\text { Öğretici Yetkinlik } \\
\text { Algısı }\end{array}$} & İl Merkezi & 126 & 11.690 & 1.969 & G. Arasi & 28.935 & 2 & 14.467 & 4.048 & 0.019 \\
\hline & İlçe & 79 & 11.822 & 1.456 & G. İçi & 793.448 & 222 & 3.574 & & \\
\hline & Köy & 20 & 10.500 & 2.743 & 3 Toplam & 822.382 & 224 & & & \\
\hline & Toplam & 225 & 11.631 & 1.916 & & & & & & \\
\hline \multirow{4}{*}{$\begin{array}{c}\text { Yönlendirebilme } \\
\text { Algısı }\end{array}$} & İl Merkezi & 126 & 7.627 & 2.010 & G. Arası & 5.359 & 2 & 2.679 & 0.550 & 0.578 \\
\hline & İlçe & 79 & 7.810 & 2.391 & G. İçi & 1082.170 & 222 & 4.875 & & \\
\hline & Köy & 20 & 8.150 & 2.621 & Toplam & 1087.529 & 224 & & & \\
\hline & Toplam & 225 & 7.737 & 2.203 & & & & & & \\
\hline \multirow{4}{*}{ ÇÖAÖ Toplam } & İl Merkezi & 126 & 47.754 & 6.097 & 7 G. Aras1 & $\begin{array}{ll}1 & 238.104\end{array}$ & 2 & 119.052 & 3.058 & 0.049 \\
\hline & İlçe & 79 & 48.822 & 5.971 & G. İçi & 8642.892 & 222 & 38.932 & & \\
\hline & Köy & 20 & 45.000 & 7.993 & 3 Toplam & 8880.996 & 224 & & & \\
\hline & Toplam & 225 & 47.884 & 6.296 & & & & & & \\
\hline
\end{tabular}

Tablo 5'te görüldüğü üzere, ANOVA sonuçlarına göre gruplar arasında "Sorumluluk Algısı" ve "Yönlendirebilme Algısı" boyutları için istatistiksel açıdan anlamlı bir farka rastlanmazken ( $\mathrm{p}>0.05)$, "Akademik Yetkinlik Algısı" $\left[\mathrm{F}_{(4-220)}=3.274, \mathrm{p}<.05\right]$ ile "Öğretici Yetkinlik Algısı" [F(4$\left.{ }_{220}=4.048, \mathrm{p}<.05\right]$ boyutları ve ölçek toplam puanı $\left[\mathrm{F}_{(4-220)}=3.058, \mathrm{p}<.05\right]$ için anlamlı farka rastlanmıştır ( $\mathrm{p}<0.05)$. ANOVA sonrası uygulanan post-hoc analiz tekniklerinden Tukey HSD seçilmiş ve yapılan testin sonuçlarına göre, "Akademik Yetkinlik Algısı" ile "Öğretici Yetkinlik Algısı" boyutları ve ölçek toplamına göre, çocukluklarını İlçede geçiren öğretmen adaylarının köyde geçiren öğretmen adaylarından anlamlı düzeyde yüksek puan aldığ 1 saptanmıştır $(p<.05)$. Ayrıca “Öğretici Yetkinlik Algısı" boyutuna göre, çocukluklarını İl merkezinde geçiren öğretmen adaylarının köyde geçiren öğretmen adaylarından anlamlı düzeyde yüksek puan aldığı saptanmıştır ( $\mathrm{p}<.05)$. 
Araştırmada; “Fen bilgisi öğretmen adaylarının çevre eğitimi öz-yeterlik algıları çevre eğitimi dersi alıp almamalarına göre anlamlı farklılık göstermekte midir?" şeklindeki alt probleme yanıt bulmak üzere ilişkisiz grup t-testi yapılmış ve sonuçlar Tablo 6 ' da sunulmuştur.

Tablo 6. Fen Bilgisi Öğretmen Adaylarının ÇÖAÖ ve Alt Boyutları için “Çevre eğitimi dersi alıp almama" Değişkenine Göre İlişkisiz Grup t-testi Sonuçları

\begin{tabular}{|c|c|c|c|c|c|c|c|c|}
\hline Ölçek Boyutları & Durum & $\mathbf{N}$ & $x$ & SS & $\mathrm{SH}_{\mathrm{x}}$ & $t$ & Sd & $p$ \\
\hline \multirow{2}{*}{$\begin{array}{c}\text { Akademik } \\
\text { Yetkinlik Algisı }\end{array}$} & Dersi Almayan & 111 & 18.955 & 3.151 & 0.299 & -1.351 & 223 & 0.178 \\
\hline & Dersi Alan & 114 & 19.561 & 3.562 & 0.333 & & & \\
\hline \multirow{2}{*}{$\begin{array}{c}\text { Sorumluluk } \\
\text { Algisı }\end{array}$} & Dersi Almayan & 111 & 9.333 & 2.701 & 0.256 & 0.446 & 223 & 0.656 \\
\hline & Dersi Alan & 114 & 9.175 & 2.611 & 0.244 & & & \\
\hline \multirow{2}{*}{$\begin{array}{c}\text { Öğretici } \\
\text { Yetkinlik Algısı }\end{array}$} & Dersi Almayan & 111 & 11.297 & 2.205 & 0.209 & -2.612 & 223 & 0.010 \\
\hline & Dersi Alan & 114 & 11.956 & 1.524 & 0.142 & & & \\
\hline \multirow{2}{*}{$\begin{array}{l}\text { Yönlendirebilme } \\
\text { Algisı }\end{array}$} & Dersi Almayan & 111 & 7.738 & 2.193 & 0.208 & 0.006 & 223 & 0.995 \\
\hline & Dersi Alan & 114 & 7.736 & 2.222 & 0.208 & & & \\
\hline \multirow[t]{2}{*}{ ÇÖAÖ Toplam } & Dersi Almayan & 111 & 47.324 & 6.648 & 0.631 & -1.319 & 223 & 0.189 \\
\hline & Dersi Alan & 114 & 48.429 & 5.912 & 0.553 & & & \\
\hline
\end{tabular}

Tablo $6^{\prime}$ da görüldüğü üzere, ilişkisiz grup t-testi sonucunda, grupların aritmetik ortalamaları ile ölçek ortalama puanı arasında anlamlı bir farklılık bulunmazken ( $p>0.05)$, “Öğretici Yetkinlik Algısı" boyutu için çevre eğitimi dersi alan fen bilgisi öğretmen adayları yönünde anlamlı bir farklılık bulunmuştur $(\mathrm{p}<0.05)$.

\section{Tartışma, Sonuç ve Öneriler}

Fen bilgisi öğretmen adaylarının çevre eğitimi öz-yeterlik algılarının çeşitli değişkenler açsından incelenmesini amaçlayan bu araştırmadan edinilen bulgulara göre aşağıdaki değerlendirmeler yapılabilmektedir.

"Fen bilgisi öğretmen adaylarının çevre eğitimi öz-yeterlik algıları hangi düzeydedir?" şeklindeki ilk soruya göre, yapılan araştırmada fen bilgisi öğretmen adaylarının çevre eğitimi öz-yeterlik algılarının orta seviyede olduğu saptanmıştır. Bu durumda, fen bilgisi öğretmen adaylarının çevre eğitimi hususunda yeterliklerinin farkında olduğu düşünülebilir. Yapılan benzer çalışmalarda da, öğretmen adaylarının çevre eğitimi öz-yeterlik algılarının orta seviyede olduğu belirtilmektedir (Gökmen, Ekici ve Öztürk, 2011; Kahyaoğlu, 2011).

"Fen bilgisi öğretmen adaylarının çevre eğitimi öz-yeterlik algıları cinsiyete göre anlamlı farklılık göstermekte midir?" şeklinde cevap aranan ikinci soruya göre, sadece "Öğretici Yetkinlik Algısı" boyutu için kadınlar lehine anlamlı fark bulunmuştur. Bu durum karşısında, kadın öğretmen adayların bir öğretici olarak erkek adaylara göre daha yetkin oldukları sonucu çıkarılabilir. Bu problem ile ilgili alanyazın araştırıldığında, çevre eğitimi öz-yeterliğin cinsiyete göre farklılaşmadığını gösterildiği araştırmalar (Gökmen, Ekici ve Öztürk, 2011; Kahyaoğlu, 2011; Zayimoğlu-Öztürk, Öztürk ve Şahin, 2015; Karakoçan, 2016) olduğu gibi, özyeterliğin cinsiyete göre farklılaştığını gösteren araştırmalar (Çağırgan, Yavuz ve Deringöl, 2018; Çavuşoğlu, 2019) da bulunmaktadır. 
“Fen bilgisi öğretmen adaylarının çevre eğitimi öz-yeterlik algıları sınıf seviyesine göre anlamlı farklılık göstermekte midir?" şeklindeki üçüncü soruya göre, ölçeğin geneli ve "Sorumluluk Algısı" boyutu açısından anlamlı bir fark bulunurken, "Akademik Yetkinlik Algısı", "Öğretici Yetkinlik Algısı" ile "Yönlendirebilme Algısı" boyutlarında anlamlı bir farklılık saptanamamıştır. Belirlenmiş olan farklılaşmanın hangi sınıf düzeylerinin aralarında olduğuna bakıldığında, 1. ve 4. sinıf öğretmen adaylarının "Sorumluluk Algısı" boyutu puanlarının 2. ve 3. sınıf öğretmen adaylarından anlamlı düzeyde yüksek olduğu, bunun dışında 4. sınıf öğretmen adaylarının ÇÖAÖ'den aldıkları puanların da 2. sınıf öğretmen adaylarından anlamlı düzeyde yüksek olduğu tespit edilmiştir. Öğretmen adayları ile birlikte yapılan Yaman, Cansüngü-Koray ve Altunçekiç'in (2004) araştırmalarının sonuçlarına göre, sınıf düzeyinin artması ile birlikte öz-yeterlik düzeyinin de arttığı belirlenmiştir. Ayrıca, öğretmen adaylarıyla Akkoyunlu ve Kurbanoğlu'nun (2003) yürüttükleri bir araştırmada 4. Sınıf öğretmen adaylarının aşağı düzeydeki diğer sınıflara göre öz-yeterliklerinin daha yüksek olduğu belirlenmiştir. Bu neticeye göre, fen bilgisi öğretmen adaylarının çevre eğitimi özyeterlik algılarının sınıf seviyesi ile doğru orantılı olarak artış göstermesinin sebebi olarak, çevre ile ilgili öğretmen adaylarının aldıkları seçimlik ya da zorunlu derslerinin 3. ile 4. sınıf düzeyinde ağırlık kazanması gösterilebilir.

"Fen bilgisi öğretmen adaylarının çevre eğitimi öz-yeterlik algıları en uzun süre yaşadıkları coğrafi bölgeye göre anlamlı farklılık göstermekte midir?" şeklindeki dördüncü soruya göre, anlamlı farklılıkların bulunduğu "Akademik Yetkinlik Algısı" ile "Yönlendirebilme Algısı" boyutları ve ölçek toplamına göre, en uzun süre İç Anadolu bölgesinde yaşayan öğretmen adaylarının, Karadeniz, Akdeniz, Ege ve Marmara bölgelerinde yaşayan öğretmen adaylarından anlamlı düzeyde yüksek puan aldığı saptanmıştır. Bu bulgu, öğretmen adaylarının çevre eğitimi öz-yeterlik algıları üzerine en uzun süre yaşadıkları coğrafi bölgelerin etkili olduğu şeklinde yorumlanabilir. Coğrafi bölge dağılımları arasında homojen bir oluşum meydana gelmediği için araştırma sonuçlarına göre coğrafi bölgelerin arasında alt boyutlar ve ölçek toplamı için anlamlı bir farklılık tespit edilmiş olsa da bu hususta doğru bir karara varılabilinmesi için daha geniş ve homojen gruplar ile araştırmanın tekrarlanması gerekmektedir. Yanı sıra, Şama (2003)'nın öğretmen adayları ile yapmış olduğu araştırmada çevreye yönelik tutum ve davranışlarının coğrafi bölge değişkenine göre farklılaşmadığı ancak puanları incelendiğinde, öğretmen adaylarının sayısının İç Anadolu Bölgesinde yoğunlaştığı da saptanmıştır.

“Fen bilgisi öğretmen adaylarının çevre eğitimi öz-yeterlik algıları çocukluğun geçirildiği yerleşim yerine göre anlamlı farklılık göstermekte midir?" biçimindeki beşinci soruya göre, "Sorumluluk Algısı" ve "Yönlendirebilme Algısı" boyutları için istatistiksel açıdan anlamlı bir farka rastlanmazken, "Akademik Yetkinlik Alg1sı" ile "Öğretici Yetkinlik Algısı" boyutları ve ölçek toplam puanı için anlamlı farka rastlanmıştır. "Akademik Yetkinlik Algısı" ile "Öğretici Yetkinlik Algısı" boyutları ve ölçek toplam puanına göre, çocukluklarını ilçede geçiren öğretmen adaylarının köyde geçiren öğretmen adaylarından anlamlı düzeyde yüksek puan aldığı saptanmıştır. Ayrıca "Öğretici Yetkinlik Algısı" boyutuna göre, çocukluklarını il merkezinde geçiren öğretmen adaylarının köyde geçiren öğretmen adaylarından anlamlı düzeyde yüksek puan aldığı da tespit edilmiştir. Bu durum, büyük şehirlerde çevreyi kirleten fazla etken bulunduğundan zararın en aza indirilmesine yönelik eğitim almaları ile açıklanabilir. Bununla birlikte, günümüzde nüfusun hılı artışı ve sanayileşme ile beraber gelen şehirleşmenin sonucu olarak yeni yerleşim alanlarının oluşmasında ağaçların tahribi, havanın, toprağın ve suyun kirlenmesi gibi çevre sorunlarının şehirlerde yaşayan insanların 
çevreye yönelik duyarlılığının artmasına neden olmuş, bu da, çevre eğitimini küçük yaşlarda yoğun olarak edinmeye başlayan öğretmen adaylarının çevre eğitimi öz-yeterlik algılarının yükselmesine yol açmış olabilir. Bu araştırma ile benzer şekilde, Erkol ve Erbasan (2018)'ın sınıf öğretmenleri ile yapmış oldukları araştırmalarında il merkezinde çalışan öğretmenlerin, kasaba ya da köyde çalışan öğretmenlere oranla çevre eğitimi öz-yeterlik algılarının daha etkili olduğu saptanmıştır. Bu durumu il merkezinde yaşayan öğretmenlerin çevresel problemlere diğer yerleşim yerlerinde yaşayan öğretmenlere göre daha çok maruz kalmalarından dolayı çevresel konulara olan ilgilerinin artması, çevreyle ilgili farkındalıklarını artırabilecek imkanlara kolaylıkla erişme sağlayabilmeleri gibi unsurların neden olabileceği şeklinde açıklamışlardır. Buna karşın öğretmen adaylarının yetiştikleri yerleşim yeri ile çevre eğitimi öz-yeterlik algıları arasında anlamlı bir fark bulunmayan araştırmalara da rastlanmaktadır (Can, 2012; Zayimoğlu-Öztürk, Öztürk ve Şahin, 2015).

"Fen bilgisi öğretmen adaylarının çevre eğitimi öz-yeterlik algı düzeyleri çevre eğitimi dersi alıp almamaları" değişkenine göre farklılaşmakta mıdır?" şeklindeki son soruya göre, sadece "Öğretici Yetkinlik Algısı" boyutu için çevre eğitimi dersini almış öğretmen adaylarının lehine anlamlı fark bulunmuştur. Bu bulgudan yola çıkarak, lisans öğrencilerinin çevreye ait öğretici yetkinlik algıları üzerine çevre eğitimi dersinin pozitif etkilerinin olduğu; öğretmen adaylarının ileride öğrencilerine çevreye karşı sorumlu ve duyarlı davranışları nasıl öğretebileceklerine ilişkin gelişerek bilinçlenme sağladıkları öngörülmektedir. Ölçek toplamına göre bakılacak olursa, anlamlı fark olmamasına karşın, dersi almış fen bilgisi öğretmen adaylarının puanlarının ortalamasının dersi almamış adaylardan yüksek çıktığı da belirlenmiştir. Bu sonuçtan hareketle, çevre eğitimi dersinin çevre eğitimine yönelik özyeterlik algılarında etkili olduğu ve fen bilgisi öğretmen adaylarına çevre eğitimi dersinin etkin bir şekilde verilmesi gerektiği düşünülmektedir. Çevre eğitimi dersini alan ve almayan öğretmen adaylarının çevre eğitimi öz-yeterlik algıları arasında anlamlı bir farklılı̆̆ın olmadığı bulgular (Zayimoğlu-Öztürk, Öztürk ve Şahin, 2015) olduğu gibi, çevre eğitimi dersini almış öğretmen adayların puanlarının, dersi almayan öğretmen adaylarının puanlarından daha yüksek çıktığının belirlendiği bulgulara da rastlanmaktadır (Aydın, 2008). $\mathrm{Bu}$ araştırmadan elde edilen sonuçlara bakılarak şu öneriler getirilebilinir: Çevre eğitimi dersini verecek olan öğretmenlerin çevre bilincine sahip olması gerektiği için, öğretmen olmadan önce eğitim gördükleri üniversitelerin fakültelerinde çevre eğitiminin üzerinde durulmalı, çevre eğitimi ve çevre bilimi gibi derslerin bazı kısımları, fakülte dışında çevre eğitimine ve çevrenin sürdürülebilirliğine yönelik farkındalığı arttıracak biçimde düzenlenmelidir. Öğretmen adaylarının çevre eğitimine yönelik öz-yeterlik algılarının yükselmesi için, üniversitede dersi veren öğretim elemanlarının da bu konuda gösterecekleri performans ve çevre eğitimi öz-yeterlik algılarını artırıcı yönde çalışmalar yapılmalıdır. Çevre eğitimi derslerine, 3 . ve 4 . sınıflarda olduğu gibi 1 . ve 2 . sinıflarda da ağırlık verilmelidir. Bu araştırmanın, farklı sınıf düzeyleri ve bölümlerde öğrenim gören daha büyük bir öğretmen adayı örneklemiyle tekrarlanması elde edilecek sonuçların genelleme yapılabilmesi olanağını artıracaktır. Araştırmanın sonucunda, fen bilgisi öğretmen adaylarının çevre eğitimi özyeterlik algıları ile ilgili elde edilen verilerin alanyazına katkılar sağlayacağı ve yapılacak diğer araştırmalara yol göstereceği düşünülmektedir. 


\section{Bilgilendirme}

Bu araştırma, 12-15 Eylül 2017'de Edirne' de gerçekleştirilen ve İzmir Biyologlar Derneği İzmir Şubesi Başkanlığı ile Trakya Üniversitesi Fen Fakültesi Biyoloji Bölümü'nin birlikte düzenlediği XIII. Uluslararası Katılımlı Ekoloji ve Çevre Kongresi'nde sözlü bildiri olarak sunulmuştur.

\section{Kaynakça}

Akkoyunlu, B., \& Kurbanoğlu, S. (2003). Öğretmen adaylarının bilgi okuryazarlı̆̆ı ve bilgisayar öz-yeterlik algıları üzerine bir çalışma. Hacettepe Üniversitesi Eğitim Fakültesi Dergisi, 24(24), 1-9.

Armor, D., Conroy-Oseguera, P., Cox, M., King, N., McDonnell, L., Pascal, A., Pauly, E., \& Zellman, G. (1976). Analysis of the school preferred reading programs in selected Los Angeles minority schools. Report No. R-2007-LAUSD. Santa Monica, CA: Rand Corporation (ERIC Document Reproduction Service No. 130 243).

Aydın, N. (2008). Sınıf öğretmeni adaylarının ve öğretmenlerinin çevre eğitimine yönelik özyeterlik inançları üzerine sınıf düzeyi, kıdem ve değer yönelimlerinin etkisi. (Yüksek Lisans Tezi, Adnan Menderes Üniversitesi, Aydın).

Bandura, A. (1986). Social foundations of thought and action: A social cognitive theory. Englewood Cliffs, NJ: Prentice-Hall.

Bandura, A. (1994). Self-efficacy. In V. S. Ramachaudran (Ed.), Encyclopedia of human behavior (Vol. 4, pp. 71-81). New York: Academic Press. (Reprinted in H.Friedman [Ed.], Encyclopedia of mental health. San Diego: Academic Press, 1998).

Bıkmaz, F. H. (1994). Sınıf öğretmenlerinin fen öğretiminde öz-yeterlik inancı ölçeğinin geçerlilik ve güvenirlik çalışması. Milli Ĕ̆itim Dergisi, 161.

Can, H. (2012). İlköğretim bölümü 1. ve 4. sınfföğrencilerinin çevreye yönelik bilgi, dünya görüşü ve çevre eğitimine yönelik öz-yeterlik inançlarının karşılaştırılması (Yüksek Lisans Tezi, Adnan Menderes Üniversitesi, Sosyal Bilimler Enstitüsü, Aydın).

Çağırgan, D., Yavuz, G., \& Deringöl, Y. (2018). Matematik öğretmen adaylarının geometrik cisimler konusuna yönelik tutumları ve geometriye yönelik öz-yeterlikleri. Ege Eğitim Dergisi, 19(2), 369-387.

Çavuşoğlu, Ü. (2019). Öğretmen adaylarının çevre eğitimi öz-yeterlilikleri ile sürdürülebilir çevreye yönelik tutumları arasındaki ilişkinin incelenmesi, (Yüksek Lisans Tezi, Kahramanmaraş Sütçü İmam Üniversitesi, Fen Bilimleri Enstitüsü, Kahramanmaraş).

ÇEDGM, (2004). Çürkiye Atlası. http://ahmetsaltik.net/arsiv/2012/06/Turkiye_Cevre_Atlasi_Cevre_Bakanligi.pdf adresinden 04.06.2019 tarihinde alınmıştır.

Doğan, M. (1997). Ulusal Çevre Eylem Planı: Eğitim ve Katılım, Türkiye Çevre Vakfı Yayınları, ISBN 975-19-1702-6, (http://ekutup.dpt.gov.tr/cevre/eylempla/doganm.pdf). 
Erkol, M., \& Erbasan, Ö. (2018). Öğretmenlerin çevre eğitimi öz-yeterliklerinin çeşitli değişkenler açısından incelenmesi. Erzincan Üniversitesi Ĕ̆itim Fakültesi Dergisi, 20(3), 810825.

Gibson, S., \& Dembo, M. H. (1984). Teacher efficacy: a construct validation, Journal of Educational Psychology, 76(4), 569-582.

Gorski, P.C., Davis, S. N., \& Reiter, A. (2012). Self-efficacy and multicultural teacher education in the United States: The factors that influence who feels qualified to be a multicultural teacher educator. Multicultural Perspectives, 14(4), 220-228.

Gökmen, A., Ekici, G., \& Öztürk, G. (2011). Biyoloji Öğretmen Adaylarının Çevre Eğitimine Yönelik Özyeterlilik Algılarının incelenmesi Üzerine Bir Çalışma. X. Ulusal Fen ve Matematik Eğitimi Kongresi, Niğde Üniversitesi, http://kongre.nigde.edu.tr/xufbmek/dosyalar/tam_metin/pdf/2470-30_05_201221_56_31.pdf adresinden 05.11.2019 tarihinde alınmıştır.

Kahyaoğlu, M. (2011). Öğretmen adaylarının öğrenme stilleri ile çevre eğitimi öz-yeterlikleri arasındaki ilişki. Eğitim Bilimleri Araştırmaları Dergisi, 1(2), 67-82.

Karakoçan, E. (2016). Sınıf öğretmenlerinin çevre eğitimine yönelik farkındalıkları. (Yüksek Lisans Tezi, Afyon Kocatepe Üniversitesi Sosyal Bilimler Enstitüsü, Afyonkarahisar).

Kurgun, E., Aydın, N., \& Tarkay, N. (2003). Çevre El Kitabı. Ankara: Aydoğdu Ofset Matbaacilik.

Leithwood, K., \& Jantzi, D. (2008). Linking Leadership to Student Learning: The Role of Collective Efficacy. Educational Administration Quarterly, 44(4), 496-528.

Miller, A. D., Ramirez, E. M., \& Murdock, T. B. (2017). The influence of teachers' self-efficacy on perceptions: Perceived teacher competence and respect and student effort and achievement. Teaching and Teacher Education, 64, 260-269.

Moseley, C., Reinke, K., \& Bookout, V. (2002). The effect of teaching outdoor environmental education on preservice teachers' attitudes toward self-efficacy and outcome expectancy. Journal of Environmental Education, 34(1), 9-15.

Moseley, C., Huss, J., \& Utley, J. (2010). Assessing k-12 teachers' personal environmental education teaching efficacy and outcome expectancy. Applied Environmental Education and Communication, 9, 5-17.

Özdemir, O. (2007). Yeni bir çevre eğitimi perspektifi: sürdürülebilir gelişme amaçlı eğitim. Eğitim ve Bilim Dergisi, 32(145).

Özdemir, A., Aydın, N., \& Akar-Vural, R. (2009). Çevre eğitimi öz-yeterlik algısı üzerine bir ölçek geliǵtirme çalıǵması. Buca Ĕ̆itim Fakültesi Dergisi, 26, 1-8.

Plevyak, L. H., Bendixen-Noe, M., Henderson, J., Roth, R. E., \& Wilke, R. (2001). Level of teacher preparation and gmplementation of ee: mandated and non-mandated ee teacher preparation states. The Journal of Environmental Education, 32(2), 28-36.

Schunk, D. (2014). Öğrenme teorileri. (Çev. M. Şahin). Ankara: Nobel Yayın Dağıtım.

Şama, E. (2003). Öğretmen adaylarının çevre sorunlarına yönelik tutumları. Gazi Üniversitesi Gazi Ĕ̆itim Fakültesi Dergisi, 23: (2), 99-110. 
Tekin, H. (1993). Measurement and evaluation in education. Ankara: Yarg1 Publications.

Trauth-Nare, A. (2015). Influence of an intensive, field-based life science course on preservice teachers' self-efficacy for environmental science teaching. Journal of Science Teacher Education, 26(5), 497-519.

Yaman, S., Cansüngü-Koray, Ö., \& Altunçekiç, A. (2004). Fen bilgisi öğretmen adaylarının özyeterlik inanç düzeylerinin incelenmesi üzerine bir araştırma. Türk Eğitim Bilimleri Dergisi, 2(3), 355-364.

Zayimoğlu-Öztürk F., Öztürk T., \& Şahin A. (2015). Sınıf öğretmeni adaylarının çevre eğitimi öz-yeterlik algılarının incelenmesi. Amasya Üniversitesi Ĕ̆itim Fakültesi Dergisi, 4 (2), 293311. 